\title{
Cell therapy in ischemic settings: Fact and fiction
}

Gino Gerosa, MD, and Chiara d'Agostino, MD

From the Department Cardiac, Thoracic, and Vascular Sciences, Cardiac Surgery Section, University of Padova Medical School, Padova, Italy.

Received for publication Nov 6, 2007; accepted for publication Dec 14, 2007.

Address for reprints: Gino Gerosa, MD, University of Padova Medical School, Cardiac Surgery Unit, Cardiologic, Thoracic, and Vascular Science, Via Giustiniani 1, 35128 Padova, Italy (E-mail: gino.gerosa@ unipd.it).

J Thorac Cardiovasc Surg 2008;135:986-90 $0022-5223 / \$ 34.00$

Copyright $\odot 2008$ by The American Association for Thoracic Surgery

doi:10.1016/j.jtcvs.2007.12.007
$\mathrm{U}$ ntil the 1990s, it had always been thought that the adult heart could not renew its cells and that the number of cells present at birth would "dictate the destiny" of this organ through a person's life. ${ }^{1}$ According to this idea, myocyte turnover did not occur, and cells formed during the embryonic and fetal life were responsible for the preservation of the heart until the end.

Apoptosis, according to this hypothesis, should not occur. The heart would rapidly lose a number of myocytes, and the remaining cells would not be able to support ventricular function.

The dogma was therefore that the heart cannot regenerate. Anversa challenged this assumption, leading to a "paradigm shift" in cardiac biology. ${ }^{2}$

\section{The Expectations}

Since Anversa showed that cardiomyocytes undergo apoptosis at a certain rate, the idea of the heart switched from a "still-life organ" to a self-renewing organ in which myocyte regeneration occurs. The injured heart may potentially act as a trigger for regenerative function; the process of repairing the damaged heart is thought to be related to the balance between regeneration and loss of myocytes. This was further confirmed recently with highly advanced mouse genetic engineering technologies allowing cellular tracking with a "fate mapping" approach. ${ }^{3}$ This technique clearly confirmed that endogenous stem cells refresh adult mammalian cardiomyocytes after myocardial infarction or pressure overload. Although an increased number of mitotic cardiomyocytes and cardiac stem cells in the infarcted heart will accelerate the regeneration of new myocardium, an excessive loss of cardiomyocytes may also be induced by the ventricular mechanical stress and altered milieu in the infarcted heart. Because the number of mitotic cardiomyocytes in human beings is very low, a negative balance between regeneration and loss of myocytes might provide a reasonable explanation as to why self-repair of the damaged heart is not seen clinically. In line with these concepts, a regenerative medicine approach to the ischemic myocardium with exogenous cell repopulation is a promising field, but the scientific community largely continues to debate the controversial results obtained to date. The question may sound provocative: are there true facts, or only fictions, in the stem cells scenario?

\section{The Reality}

Several authors have demonstrated that injections of mixed populations of stem cells could represent a successful approach to the treatment of ischemic heart disease. The first clinical experience was described by Menasché and colleagues. ${ }^{4}$ In this preliminary study, the authors treated a single patient with low ejection fraction (35\%), akinetic segments, and viable and ischemic areas with injection, during heart surgery, of autologous skeletal myoblast. At 1-year follow-up, ejection fraction had increased and symptoms improved.

Strauer and associates ${ }^{5}$ in 2002 enrolled 20 patients with myocardial infarction and treated 10 of them by intracoronary transplantation of autologous mononuclear bone marrow cells in addition to standard therapy. After 5 to 9 days from myocardial infarction, those cells were isolated by Ficoll density separation method from bone marrow aspirated from the ilium of the patients. Cells were then retransplanted into the infarcted area by the use of a balloon angioplasty. After 3 months, comparison between the control and the cell-treated groups showed interesting differences: the infarct 
region was significantly decreased in the cell-treated group, as was the perfusion defect, whereas the left ventricle ejection fraction did not differ between the two groups.

Other studies have been recently published: the TOPCARE-AMI trial ${ }^{6}$ tested safety, feasibility, and potential effects on parameters of cardiac functions of intracoronary injections of either bone marrow-derived stem cells or circulating progenitor cells. Invasive follow-up at 4 months by left ventricular angiography showed significant increase in ejection fraction and decrease in end-systolic volume in both groups; at 1 year, a noninvasive follow-up with contrastenhanced magnetic resonance, revealed an increased ejection-fraction and a reduced infarct size.

Chen and colleagues ${ }^{7}$ treated 34 patients with cell transplantation after percutaneous coronary intervention. They evaluated the left ventricular function (by echocardiography and positron emission tomography) 3 and 6 months after implantation.

Very recently, three more studies were published reporting results of stem cell transplantation in acute ischemic settings, adding controversies to the debate..$^{8-10}$ These studies were the first prospective, randomized analyses; nevertheless, all these investigations had the same limits: the patients enrolled were few, and the follow-up period was relatively short. Only the BOOST trial ${ }^{11}$ reported results with a follow-up as long as 18 months. Unfortunately, the BOOST authors concluded that a single intracoronary injection of bone marrow-derived cells (BMCs) did not provide long-term improvement of left ventricular systolic function after acute myocardial infarction relative to a randomized control group; however, this study did suggest an acceleration by BMC therapy (at 6 months) of left ventricular ejection fraction recovery after acute myocardial infarction.

After the enthusiasm for Anversa results, these preliminary studies did not fulfill the expectation. Different reasons have been investigated to explain the controversial efficacy of stem cell therapy affecting the final translation from basic science to clinical practice.

\section{The Unresolved Issues}

Many important issues are still unresolved:

- Stem cell selection

- Modes of cell delivery

- Ability to retain efficacy

\section{Stem Cell Selection}

Different types of adult progenitor cells have been tested, all autologous to avoid tissue rejection. The first cells to be proposed as surrogate for cardiomyocytes were skeletal muscle myoblasts, undifferentiated proliferation-competent cells that serve as precursor to skeletal muscle. ${ }^{12}$ Human myoblasts are isolated from skeletal muscles biopsy samples, expanded ex vivo, and injected directly into the ventricular wall. Bone marrow is, indeed, the most frequently used source of cells for cardiac repair. It contains a variety of progenitor cells: hematopoietic stem cells, side population cells (which account for most long-term self-renewal), mesenchymal stem cells, and multipotent adult progenitor cells. Bone marrow is aspirated, the entire mononuclear cell fraction or specific subpopulations are obtained, and isolated cells are injected directly into the heart, without ex vivo expansion.

Peripheral blood-derived progenitor cells are also used. They are isolated from mononuclear blood cells and selected ex vivo by culturing in endothelium-specific medium before reinjection. $^{2}$

Other cell types have been investigated, further fueling the expectations: fat tissue-derived multipotent stem cells ${ }^{13}$ and amniotic stem cells. ${ }^{14}$ The latter are fully undifferentiated and pluripotent, are easily obtained from routine clinical amniocentesis specimens, and multiply indefinitely, apparently without forming tumors. On the one hand, a study from our group ${ }^{17}$ has demonstrated that, despite the high expansion capacity, amniotic fluid-derived mesenchymal cells, at least in the swine model and in naive, unmanipulated conditions, are inadequate to support regeneration of cardiogenic cells. Amniotic fluid-derived mesenchymal cells do not seem to survive long enough in the periphery of the ischemic lesion, nor to give rise to a target-specific, committed progeny. On the other hand, another study from our group, ${ }^{15}$ with a rat model of mild cryoinjury, has shown that endothelial cells and cardiomyocytelike cells originated mostly from transplanted amniotic fluid-derived mesenchymal cells, rather than from bone marrow-derived mesenchymal stem cells. This finding clearly highlights the extreme difficulty of identifying suitable animal models for study purpose in regenerative medicine and transferring these animal models to clinical perspectives.

\section{Modes of Cell Delivery}

Different techniques of delivery have been proposed to achieve transplantation of a sufficient number of cells into the myocardial region and to achieve maximum retention of cells within the area. ${ }^{2}$ The three most frequent modes of delivery are intracoronary, percutaneous endocardial, and direct intramyocardial during surgery. The intracoronary injection has the advantage that cells may travel directly into myocardial regions in which nutrients and oxygen are preserved, granting engraftment survival. On the other hand, cellular homing requires migration out of the vessel into the surrounding tissue. Although bone marrow-derived stem cells can extravasate, skeletal myoblasts cannot; this can obstruct microcirculation after intra-arterial administration, inducing microembolic events.

Direct delivery of cells into satellite scar tissue (endocardially or epicardially) or area of hibernating myocardium (in chronic ischemia) by needle injection might avoid the risk of embolic events, but it can cause myocardial wall perforation ${ }^{12}$ 
when performed endocardially. These techniques also require additional investigation to prove their efficacy, because the mechanism of action is not clearly understood.

Stem cells could, on the one hand, promote neoangiogenesis and neovascularization and might, on the other hand, transdifferentiate into cardiomyocytes, depending on the host environment (acute or chronic ischemia). Nevertheless, looking at the ability of the transplanted stem cells to transdifferentiate in cardiomyocytes in different animal models, the results are strongly controversial. ${ }^{15-17}$

A paracrine effect has also been postulated. Secretion of growth factors and cytokines could indirectly promote survival of cardiomyocytes, inhibiting apoptosis, leading to mobilization of progenitor cells, and reversing cardiac remodeling.

A new approach was proposed by Erbs and coworkers ${ }^{18}$ in the REPAIR-AMI trial. The authors of this study focused their attention on the microvascular function, evaluating the coronary flow reserve in the infarcted artery and in a reference vessel by intracoronary Doppler ultrasonography at the time of the study therapy (4 days after acute myocardial infarction) and at 4 months of follow-up. Coronary flow reserve in the infarcted artery of the BMC-treated patients increased markedly by $90 \%$, whereas in the control group the increase was minimal. A considerable reduction in the BMC-treated patients of the adenosine-induced vascular resistance index (relative to the control group) further confirmed these results.

The normalization of coronary flow reserve of BMCtreated patients is consistent with the hypothesis that stem cells reverse remodeling of the cardiovascular tree in the infarcted area. Dysfunctional microvessels in the infarcted area could be replaced by new and functional vessels, while growth factors and cytokines released from the injected progenitor cells, in the border area, could promote the growth and remodeling of the surviving blood vessel. ${ }^{12,18}$

A promising field is represented by use of biomaterials for improving the delivery, the adhesion, and the differentiation of stem cells. Very recently, tissue engineering strategies have exploited the strategy of cellular transplantation combined with biodegradable biomaterials to create viable myocardial replacement tissue. Biodegradable polymers may act as temporary scaffolds, providing a template for new viable tissue and supporting the cells, ${ }^{19}$ giving them chemical stability or degradability, cytocompatibility, cellular adhesion, proliferation, and mechanical strength. ${ }^{20}$ Modification of different parameters, such as physicochemical properties (surface charge) and surface topography, might influence and improve cell-material interactions. ${ }^{20,21}$ The topography and the type and density of chemical functionalities of polymer surfaces can be conveniently modified for tissue engineering by means of cold plasma technology, ${ }^{22}$ with the aim of driving eukaryotic cells in in vitro experiments. Such a controlled surface chemistry of polymers allows achievement of the ambitious goal of driving the biologic responses at the material-biologic fluid interface. It has been shown, ${ }^{23}$ in fact, that with cold plasma aid it is possible to drive the behavior of cells in tissue engineering at three levels:

- the external level, tuning the number and the shapes of the cells,

- the internal level, the modulation of cytoskeleton plasticity,

- the functional level, the modulation of the functional expression of cells.

For specific cardiac applications, biomaterials need to be elastomeric. The material must be able to meet the mechanical demands of cardiac tissue without disintegrating. ${ }^{19}$ It must also support angiogenesis and survive the ischemic period after infarction. Both extracellular matrix based (collagen type I, extracellular matrix proteins, gelatin meshes, or modified collagen) and non-matrix-based materials (polystyrene beads and collagen threads, polyglycolic acid, caprolatone-co-L-lactide ${ }^{24}$ ) are currently under investigation. ${ }^{25}$

This is a promising field that needs to be further elucidated. The studies that have been already conducted have shown that final results of stem cell-biomaterial combinations for cell-based therapies are multifactorial.

\section{Ability to Retain Efficacy}

As mentioned previously, most of the clinical studies have a limited follow up. Only the BOOST trial has presented results at 18 months. These results are indeed not encouraging, considering that recovery in left ventricular ejection fraction seen at 6-months evaluation was lost at 18 months. The BOOST authors concluded that stem cells might accelerate recovery, but they do not maintain it with time. This observation supports the hypothesis that multiple sequential injections should be performed at defined intervals.

\section{The End of Hope, or the Beginning of a New Era?}

It is clear that a complete understanding of stem cell biology would have an enormous impact on the ability to optimize clinical application. Safety of cell therapy is another issue that needs to be evaluated very carefully. Although no major side effects have been described to date, it is important to discuss some potential complications of stem cell injections, such as an increased risk of arrhythmias, coronary restenosis, or increased incidence of tumors and teratomas. Menasché and coworkers ${ }^{26}$ described 4 cases of ventricular tachycardia at $11,12,13$, and 22 days after transpericardial injection of skeletal myoblasts. A proarrhythmic effect was also found by Smits and coworkers ${ }^{27}$ with myoblasts delivered by a transvascular route. This effect of skeletal myoblast injection is probably due either to the lack of electrical coupling of myoblasts with the cardiac myocytes in the surrounding area or to a slowed conduction, both of which would promote 
reentrant arrhythmias. ${ }^{28}$ An intriguing solution to this problem, proposed by Abraham and colleagues, ${ }^{29}$ uses myoblasts genetically engineered to express gap junction protein connexin 43; this has shown decreased arrhythmogenicity.

Coronary restenosis was described by Kang and associates $^{30}$ after intracoronary injections of peripheral blood stem cells in myocardial infarction and stent placement. Injection of bone marrow-derived stem cells has also been associated with increased incidence of new lesions in unstented vessels. This phenomenon could be due to an increased adhesion capacity of cells when delivered intracoronarily at high concentration. $^{28}$

It is nevertheless reassuring that no clinical trials have ever described an increased incidence of tumor formation. The major concerns are related to embryonic cells and their potential to form teratoma, as suggested by Thomson and colleagues' injection of embryonic cells into a skeletal muscle. ${ }^{31}$

No current therapies have been shown to lead to a reduction in scar size after myocardial infarction. ${ }^{2}$ Cell transplantation has the potential to rebuild the injured heart, regenerating the damaged myocardium. The injected progenitor cells should have the ability to replace both morphologically and functionally the lost myocytes, acquiring contractility and electrical coupling with the native myocardium. Many questions need to be addressed for success in this effort. Too many variables are still present in different studies, and appropriate cells, appropriate time, and appropriate mode of delivery have yet to be clarified. Adequate follow-up of patients must be scheduled to evaluate the effectiveness of cell therapy with time.

As with the initial experience with heart transplantation, cell therapy, after the pioneering work and initial clamor arising from the fascinating experiments of Anversa's laboratory, has partially disappointed our expectations. Nevertheless, in heart transplantation cyclosporine was eventually revealed as a key element needed for transplantation to succeed. Nowadays, we have to understand and identify such key elements to bring cell therapy from laboratories to patients. To answer the initial questions, stem cells can definitively work and can ameliorate myocardial function. This is a proof of concept. How they work and for how long are the questions that remain to be addressed.

\section{References}

1. Anversa P, Leri A, Rota M, Hosoda T, Bearzi C, Urbanek K, et al. Concise review: stem cells, myocardial regeneration, and methodological artifacts. Stem Cells. 2007;25:589-601.

2. Kocher AA, Schlechta B, Gasparovicova A, Wolner E, Bonaros N, Laufer G. Stem cells and cardiac regeneration. Transpl Int. 2007;20: 731-46.

3. Hsieh PC, Segers VF, Davis ME, MacGillivray C, Gannon J, Molkentin JD, et al. Evidence from a genetic fate-mapping study that stem cells refresh adult mammalian cardiomyocytes after injury. Nat Med. 2007;13:970-4.

4. Menasché P, Hagège AA, Scorsin M, Pouzet B, Desnos M, Duboc D, et al. Myoblast transplantation for heart failure. Lancet. 2001;357:279-80.
5. Strauer BE, Brehm M, Zeus T, Köstering M, Hernandez A, Sorg RV, et al. Repair of infarcted myocardium by autologous intracoronary mononuclear bone marrow cell transplantation in humans. Circulation. 2002;106:1913-8

6. Schächinger V, Assmus B, Britten MB, Honold J, Lehmann R, Teupe C, et al. Transplantation of progenitor cells and regeneration enhancement in acute myocardial infarction: final one-year results of the TOPCAREAMI Trial. J Am Coll Cardiol. 2004;44:1690-9.

7. Chen SL, Fang WW, Ye F, Liu YH, Qian J, Shan SJ, et al. Effect on left ventricular function of intracoronary transplantation of autologous bone marrow mesenchymal stem cell in patients with acute myocardial infarction. Am J Cardiol. 2004;94:92-5.

8. Lunde K, Solheim S, Aakhus S, Arnesen H, Abdelnoor M, Egeland T, et al. Intracoronary injection of mononuclear bone marrow cells in acute myocardial infarction. $N$ Engl J Med. 2006;355:1199-209.

9. Schächinger V, Erbs S, Elsässer A, Haberbosch W, Hambrecht R, Hölschermann $\mathrm{H}$, et al. Intracoronary bone marrow-derived progenitor cells in acute myocardial infarction. N Engl J Med. 2006;355:1210-21.

10. Assmus B, Honold J, Schächinger V, Britten MB, Fischer-Rasokat U, Lehmann R, et al. Transcoronary transplantation of progenitor cells after myocardial infarction. $N$ Engl J Med. 2006;355:1222-32.

11. Meyer GP, Wollert KC, Lotz J, Steffens J, Lippolt P, Fichtner S, et al. Intracoronary bone marrow cell transfer after myocardial infarction: eighteen months' follow-up data from the randomized, controlled BOOST (BOne marrOw transfer to enhance ST-elevation infarct regeneration) trial. Circulation. 2006;113:1287-94.

12. Dimmeler S, Zeiher AM, Schneider MD. Unchain my heart: the scientific foundations of cardiac repair. J Clin Invest. 2005;115:572-83.

13. Fraser JK, Schreiber R, Strem B, Zhu M, Alfonso Z, Wulur I, et al. Plasticity of human adipose stem cells toward endothelial cells and cardiomyocytes. Nat Clin Pract Cardiovasc Med. 2006;3 Suppl 1:S33-7.

14. De Coppi P, Bartsch G Jr, Siddiqui MM, Xu T, Santos CC, Perin L, et al. Isolation of amniotic stem cell lines with potential for therapy. Nat Biotechnol. 2007;25:100-6.

15. Iop L, Chiavegato A, Callegari A, Bollini S, Piccoli M, Pozzobon M, et al. Different cardiovascular potential of adult- and fetal-type mesenchymal stem cells in a rat model of heart cryoinjury. Cell Transplant. In press 2008.

16. Chiavegato A, Bollini S, Pozzobon M, Callegari A, Gasparotto L, Taiani J, et al. Human amniotic fluid-derived stem cells are rejected after transplantation in the myocardium of normal, ischemic, immuno-suppressed or immuno-deficient rat. J Mol Cell Cardiol. 2007;42:746-59.

17. Sartore S, Lenzi M, Angelini A, Chiavegato A, Gasparotto L, De Coppi P, et al. Amniotic mesenchymal cells autotransplanted in a porcine model of cardiac ischemia do not differentiate to cardiogenic phenotypes. Eur J Cardiothorac Surg. 2005;28:677-84.

18. Erbs S, Linke A, Schächinger V, Assmus B, Thiele H, Diederich KW, et al. Restoration of microvascular function in the infarct-related artery by intracoronary transplantation of bone marrow progenitor cells in patients with acute myocardial infarction: the Doppler Substudy of the Reinfusion of Enriched Progenitor Cells and Infarct Remodeling in Acute Myocardial Infarction (REPAIR-AMI) trial. Circulation. 2007; 116:366-74.

19. Alperin C, Zandstra PW, Woodhouse KA. Polyurethane films seeded with embryonic stem cell-derived cardiomyocytes for use in cardiac tissue engineering applications. Biomaterials. 2005;26:7377-86.

20. Neuss S, Apel C, Buttler P, Denecke B, Dhanasingh A, Ding X, et al. Assessment of stem cell/biomaterial combinations for stem cell-based tissue engineering. Biomaterials. 2008;29:302-13.

21. Wei J, Yoshinari M, Takemoto S, Hattori M, Kawada E, Liu B, et al. Adhesion of mouse fibroblasts on hexamethyldisiloxane surfaces with wide range of wet. J Biomed Mater Res B Appl Biomater. 2007;81:66-75.

22. Brétagnol F, Valsesia A, Ceccone G, Colpo P, Gilliland D, Cerotti L, et al. Surface functionalization and patterning techniques to design interfaces for biomedical and biosensor applications. Plasma Process Polym. 2006;3:443-55.

23. d'Agostino R, Favia P, Sardella E, Nardulli M, Lopez L, Pistillo BR, et al. Plasma tuning of surface chemistry for driving cell behavior. Proc of 18th International Symposium on Plasma Chemistry, International Plasma Chemistry Society, Publ, p. 658, August 26-31, 2007 Kyoto (Japan). 
24. Ozawa T, Mickle DA, Weisel RD, Koyama N, Ozawa S, Li RK. Optimal biomaterial for creation of autologous cardiac grafts. Circulation. 2002; 106(12 Suppl. 1):I176-82.

25. Zimmermann WH, Melnychenko I, Eschenhagen T. Engineered heart tissue for regeneration of diseased hearts. Biomaterials. 2004;25: 1639-47.

26. Menasché $P$, Hagège AA, Vilquin JT, Desnos $M$, Abergel $E$, Pouzet B, et al. Autologous skeletal myoblast transplantation for severe postinfarction left ventricular dysfunction. $J$ Am Coll Cardiol. 2003;41:1078-83.

27. Smits PC, van Geuns RJ, Poldermans D, Bountioukos M, Onderwater EE, Lee $\mathrm{CH}$, et al. Catheter-based intramyocardial injection of autologous skeletal myoblasts as a primary treatment of ischemic heart failure: clinical experience with six-month follow-up. J Am Coll Cardiol. 2003;42:2063-9.
28. Oettgen P, Boyle AJ, Schulman SP, Hare JM. Cardiac stem cell therapy. Need for optimization of efficacy and safety monitoring. Circulation. 2006;114:353-8.

29. Abraham MR, Henrikson CA, Tung L, Chang MG, Aon M, Xue T, et al. Antiarrhythmic engineering of skeletal myoblasts for cardiac transplantation. Circ Res. 2005;97:159-67.

30. Kang HJ, Kim HS, Zhang SY, Park KW, Cho HJ, Koo BK, et al. Effects of intracoronary infusion of peripheral blood stem-cells mobilised with granulocyte-colony stimulating factor on left ventricular systolic function and restenosis after coronary stenting in myocardial infarction: the MAGIC cell randomised clinical trial. Lancet. 2004;363. 751-6.

31. Thomson JA, Itskovitz-Eldor J, Shapiro SS, Waknitz MA, Swiergiel JJ, Marshall VS, et al. Embryonic stem cell lines derived from human blastocysts. Science. 1998;282:1145-7. 